\title{
INDICATORS OF THE AGRICULTURAL INDUSTRY MANAGEMENT SYSTEM: INNOVATION AND INVESTMENT READINESS DUE TO THE DIGITAL AND TECHNOLOGICAL TRANSFORMATION FROM THE PERSPECTIVE OF AN ONTOLOGICAL APPROACH
}

\author{
Anna $V$. Shokhnekh ${ }^{1, *}$ \\ ${ }^{1}$ Volgograd State Socio-Pedagogical University, Volgograd, Russia
}

\begin{abstract}
The article presents indicators of the agricultural industry management system: doing business in a digital and technological transformation from the perspective of an ontological approach. It is important to note that it is impossible to transform under the requirements of the modern world without the introduction of innovation. However, innovation is always marked by financial costs and loss of time, which reduces the innovative activity of organizations in the agricultural sector, and, therefore, determines the diagnosis of innovation and investment policy. Forming an indicative methodology for justifying, measuring and developing the readiness of the agricultural sector's management system to conduct entrepreneurship in the context of digital and technological transformation from the perspective of an ontological approach is evident as a process of formation and implementation of investment potential to ensure the release of innovative competitive products based on an advanced technology platform.
\end{abstract}

\section{Introduction}

The relevance of adopting the innovation and investment policy in ensuring the economic security of agricultural organizations in the agricultural sector is especially evident in due to the techno-economic modernization. The issues of development and implementation of innovation and investment policies at the mesoscale and microscale are focused on sustainable development and a resource-based approach to the final results of scientific research and experimental outcome at the initial stage of agricultural production. These guidelines make it possible to profit on the basis of expanding and updating the range of agricultural products, improving agricultural production technologies, management, as well as improving taste, avoiding the use of genetically modified organisms, increasing shelf life due to the implementation of new buildings, structures, installations and usage of different types of agricultural production. [Asriyants K.G., 2016; Melnikova Y.V., 2020; Rogachev A.F., 2015; Rumbaeva N.N.,2007].

\section{Discussion}

At all levels of the world economic system the development dialectic of innovative investment activity in the field of agricultural production is realized through the use of highly effective tools, when crisis phenomena intensify. Technologies of the modern theory of innovation, synergy, cybernetics, systems concepts, methodological developments in the project of automation and informatization of agricultural production concepts and the formation of ultra-efficient innovative investment production systems are also used. They are presented in the form of balanced coexistence of research and agro-industrial potentials [Shogenov A.M., 2004; Kunitsa M.N.,2017; Ganieva I.A., 2019; Gerasina Y.A., 2011; Makarova N.N.,2019].

The confirmation of innovation and investment policy's directions is explained by statements about competitive advantages, not only in production, but also in the field of product marketing, which involves the development of the production infrastructure of the agricultural sector. Studies show that the forming and implementing of innovation and investment policy is due to competition. The transition to a new level requires not just improving the facility, but its development based on the use of new methods and principles, which indicates the importance of constantly improving human resources by increasing its potential and introducing innovations in the organization of the agricultural industry [Gladysheva A.L., 2014; Salomatin V.A., 2011; Melnikova Y.V., 2020; Shcherbina T.A., 2019; Shokhnekh A.V., 2020].

Creating an indicative methodology for the justification, measurement and development of readiness of the agricultural sector's management system to conduct business in the context of digital and

\footnotetext{
"Corresponding author: shokhnekh@yandex.ru
} 
technological transformation from the perspective of the ontological approach is considered as a fundamentally new approach to production, distribution, exchange, reproduction in terms of techno-economic modernization and is based on a specific example, idea or direction of activity, which should bring a financial, social or technological result to ensure the economic security of agricultural organizations. However, the study of innovation and investment activities of agricultural organizations presents a systematic request aimed at improving the technical and technological aspects, including the development of new trends in the infrastructures' development, which take into account the effects of favorable and unfavorable factors of external influence and the internal environment. It is a socially loaded model of the economy built on innovation and investment activity and used in the practice of economically developed countries that provide fairly high standards of social guarantees.

It should be noted that the innovation and investment policy meets international and national environmental safety requirements that have been stated in international agreements such as: 1) Rio Declaration on Environment and Development: adopted by the UN Conference Environment and Development, Rio de Janeiro (June 314, 1992); 2) Johannesburg Declaration on Sustainable Development: adopted at the World Summit on Sustainable Development [Johannesburg, South Africa, $\begin{array}{llll}\text { August } & 26 \quad \text { - } & \text { September 4, }\end{array}$ http://www.un.org/ru/documents/decl_conv/decl_enviro nment.shtml] [Melnikova Y.V., 2020; Shokhnekh A.V. 2019; Shokhnekh A.V., 2020].

Also Russia has determined the directions of state policy in the field of environmental safety until 2030. The key goal of constructing a system of measures and indicators in the innovation and investment policy of agricultural organizations in the agricultural sector is to ensure the environmental and economic security of sustainable development of the economy.

The priority tasks of the system of measures and indicators in the innovation and investment policy of agricultural organizations in the agricultural sector:

1) determining of environmental and economic safety criteria for sustainable development of the global economy;

2) building a country's balance for environmental and economic security of sustainable development of the national economy;

3) creating innovative investment policies of agricultural organizations for the sustainable development of the regional economy;

4) allocating negative externalities caused by the innovation and investment policy of agricultural organizations in the agricultural sector, which are external effects that reduce the welfare of third parties (heavy traffic, usage of natural, water and land resources in the production process causes pollution of air, water, land and waste accumulation);

5) highlighting the positive externalities caused by the innovation and investment policy of agricultural organizations in the agricultural sector, which are external effects that increase the welfare of third parties (economic entity's investments in drainage facilities, which controls the flow of water, construction of the road, construction of lightning conductors);

6) forming criteria for temporal externalities (temporary, historical) due to the innovation and investment policy of agricultural organizations in the agricultural sector for the sustainable development of an innovative population, without reducing the resource capabilities of the following generations:

- implementing of negative external restrictions to the future generation by the innovative population: reduction of oil and gas reserves, minerals, depletion of agricultural land, which determine significant energy and food difficulties in the future;

- transfering of positive temporal externalities lies in the technological development of scientific achievements, namely the use of solar, water, wind energy, magnetic energy;

7) creating criteria for interindustry externalities, due to the innovation and investment policy of agricultural organizations in the agro-industrial complex, where resource-processing and environmental exploiting sectors cause significant damage to other sectors of the economy;

8) forming global externalities criteria, due to the innovation and investment policy of agricultural organizations in the agricultural sector, manifested in transboundary pollution of neighboring states (emissions of chemical compounds, pollution of rivers, air, changes in sea level, sharp fluctuations in climate change);

9) creating criteria for meso-externalities, due to the innovation-investment policy of agricultural organizations in the agricultural sector in transboundary pollution of neighboring regions at the mesoscale (emissions of chemical compounds, pollution of rivers, air; for example, regions located in the upper riverbed countries must bear the additional costs of water purification of the "lower" regions;

10) forming criteria for local externalities, called within the scope of the study, due to the innovation and investment policies of agricultural organizations in the agricultural sector (economic entities, the population, natural objects, resources, and so on).

\section{Materials and methods}

To test the proposed hypothesis, a statistical analysis and synthesis of ontological approaches to innovation and investment policy are used in order to determine the dependence of various indicators of innovation and investment policies of agricultural organizations on the level of digitalization of the market environment. It is advisable to synthesize financial and non-financial components according to the indicated criteria. So, (nonfinancial) reporting system is formed to ensure the innovation-investment policy of agricultural organizations in international practice. It presents environmental, economic and social guarantees. Such environmental, economic and social guarantees are confirmed by auditors. These statements are a part of the 


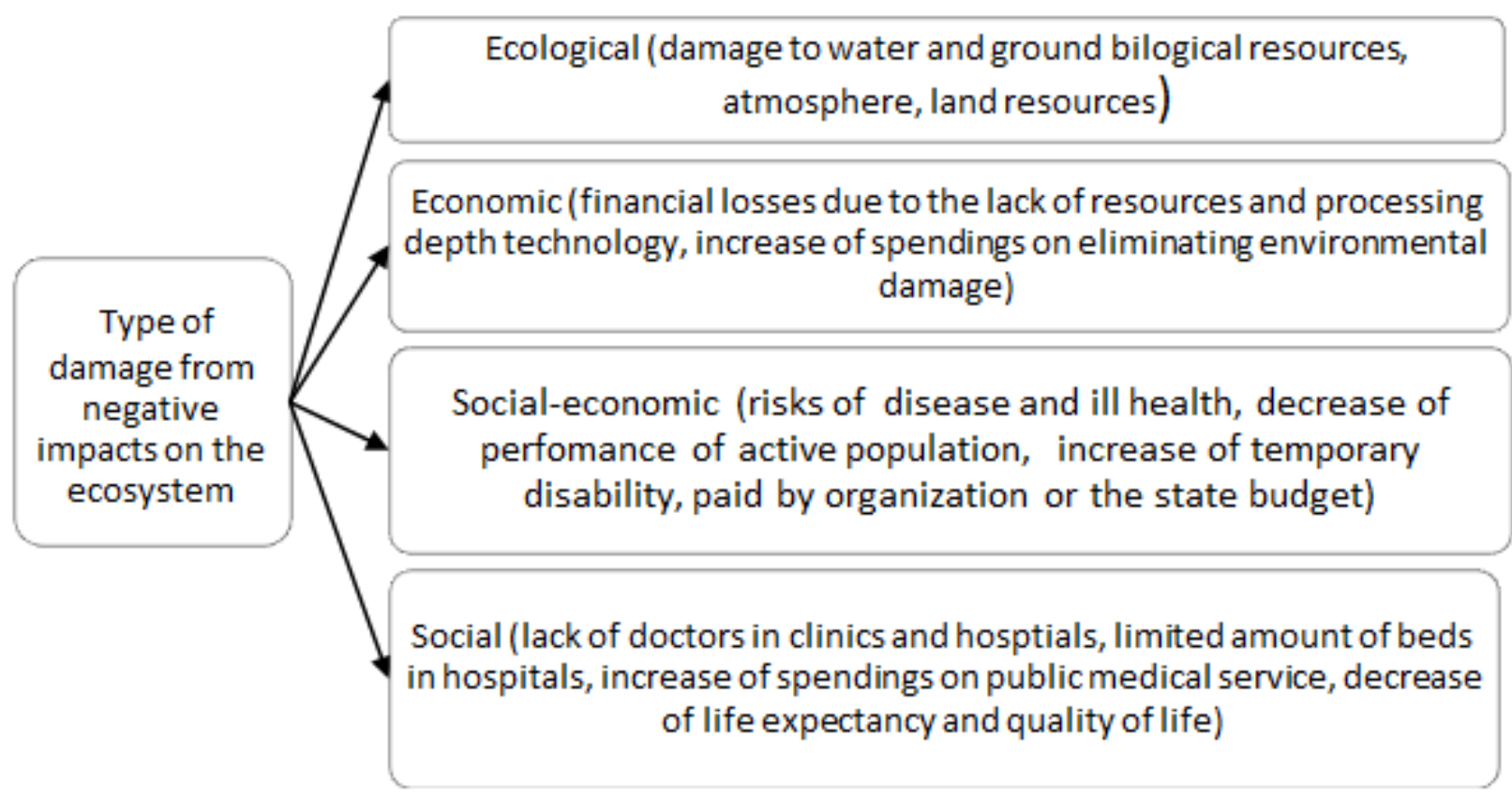

Fig. 1. Results of the impact of negative factors on the ecosystem indicator system (Source: compiled based on the study of the theory [Melnikova Yu.V., 2019, Shokhnekh A.V. 2019 Shokhnekh A.V., 2020]).

consolidated sustainable development reporting system (GRI - Global Reporting Initiative).

Defining a system of measures and indicators of innovation and investment policy of agricultural organizations in the agro-industrial complex is necessary for further analysis and synthesis in the process of forming sub-accounts, as an obligatory component of financial reporting. Sub-accounting system will allow collecting of classified data to manage and ensure innovation and investment policy. It is expedient to single out subjects and objects and give their characteristics for further research on methods for achieving the goal and solving problems.

\section{Research part}

Managing and ensuring innovation and investment policy of agricultural organizations in the agricultural sector involves reducing environmental impacts, including a certain level of resource extraction, heat, radiation, pollution of the natural environment, which will mitigate the consequences for all living organisms as on a specific territory, and for the entire ecosystem.

Currently, there are four distinguished types of damage from negative impacts in the classification of ecosystem impacts (Figure 1).

The analysis of possible directions of the innovation and investment policy of agricultural organizations revealed an institutional characteristic, which is marked by tracing and copying the successful experience of developed countries, as well as constructing a new project that takes into account the internal conditions of innovation programs.

The solution of these problems must be carried out with participation of the state, which should apply risk minimization mechanisms in violation of the ecosystem balance. Ensuring ecological balance is one of the important functions of the state and the world community. Therefore, the budget formed to implement the state functions should take into account the system of measures and indicators in the innovation and investment policy of agricultural organizations.

To determine the indicators, it is important to take into account that sustainable agricultural development should go along the innovative direction to profitability [Saifetdinov A.R., 2018; Grudkina T.I., 2014; Taroyan V.M., 2015; Dryomina G.A., 2012; Rogachev A.F., 2018]. Such indicators can be distinguished into groups, each of which reflects their essential characteristic (figure 2).

The presented elements of innovation and investment policy allow developing a system of indicators in the innovation and investment policy of agricultural organizations: 1) indicators of the ontology and methodology of innovations in agricultural activity; 2) indicators of ontology and methodology of investment design in agricultural activities; 3) indicators of ontology and methodology of innovation and investment policy in agricultural activities [Melnikova Yu.V., 2019, Shokhnekh A.V. 2019; Shokhnekh A.V., 2020].

\section{Final part}

1. Indicators of ontology and methodology of innovations in agricultural activity. The presented indicators of ontology and methodology of innovations in agricultural activity analyze innovative projects according to the following content: 1) the presence of completely new or "well" forgotten old ideas that were not implemented due to the lack of mass knowledge, skills at a cognitive level; 2) the presence of mechanisms to simplify the process, reducing the number of 


\section{Groups of indicators of innovation and investment development of agricultural organizations for indicative methodology}

\begin{tabular}{|c|c|c|c|}
\hline$=$ & $\begin{array}{l}\text { 1) Introduction of new technologies to ensure the economic affordabil- } \\
\text { ity of raw materials and products for the entire population; } \\
\text { Transformation of mechanisms aimed at the availability of raw mate- } \\
\text { rials and products, allowing to develop interregional integration in } \\
\text { the field of agricultural markets and commodity supply; } \\
\text { 3) Transformation of transport infrastructure in the imnovation and in- } \\
\text { vestment policy of agricultural organizations in order to guarantee } \\
\text { rhythmic supply of the needs of the population with fresh products; } \\
\text { 4) Tansformation and increase in the number of objects of trade infra- } \\
\text { structure of agricultural products }\end{array}$ & $\begin{array}{l}\text { 1. Analysis of } \\
\text { technological } \\
\text { transfor- } \\
\text { mation } \\
\text { mechanisms } \\
\text { in innovation } \\
\text { and invest- } \\
\text { ment policy }\end{array}$ & : \\
\hline : & $\begin{array}{l}\text { 1) Transformation of production processes of safe products that meet } \\
\text { the requirements of Russian legislation; } \\
\text { 2) Transformation of control methods over the processes of produc } \\
\text { tion, processing, procurement, storage, transportation and sale; } \\
\text { 3) Transformation of the process of introducing new technologies of } \\
\text { deep and complex processing of raw materials, storage and transporta } \\
\text { tion methods }\end{array}$ & $\begin{array}{l}\text { 2. Analysis of } \\
\text { transfor- } \\
\text { mation } \\
\text { of economic } \\
\text { security con- } \\
\text { trol }\end{array}$ & 司 \\
\hline : & $\begin{array}{l}\text { 1) Transformation of the processes of scientific potential development } \\
\text { to the innovation and investment policy of the agro-industrial complex } \\
\text { 2) Transformation of the measures implementation to prevent the out- } \\
\text { flow of highly qualified scientific personnel from the industry, region, } \\
\text { country; } \\
\text { 3) Transformation of processes to increase the pace of structural and } \\
\text { technological imnovation and investment activities to restore land for } \\
\text { the reproduction of natural and environmental potential; } \\
\text { 4) Transformation of the development process of training and increas- } \\
\text { mg the labor resources of agricultural organizations capable of realiz- } \\
\text { mg the tasks of an innovative economy; } \\
\text { 5) Transformation of the mechanisms managing the market of prod- } \\
\text { lacts, raw materials and goods, their price imbalances in the agricultur- } \\
\text { la sector; } \\
\text { 5) Transformation of state support mechanisms for the development of } \\
\text { gnnovation and investment policies of agricultural organizations }\end{array}$ & $\begin{array}{l}\text { 3. Analysis } \\
\text { of transfor- } \\
\text { mation } \\
\text { of processes } \\
\text { raw materi- } \\
\text { als and } \\
\text { of goods } \\
\text { production } \\
\text { in the inno- } \\
\text { vation- } \\
\text { investment- } \\
\text { policy of } \\
\text { agricultural } \\
\text { organiza- } \\
\text { tions }\end{array}$ & 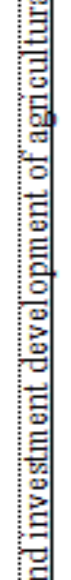 \\
\hline : & $\begin{array}{l}\text { 1) Transfomation of the process of social arrangement of rural set } \\
\text { lements for the financial implementation of social programs; } \\
\text { 2) Transformation of the effectiveness monitoring process of inno } \\
\text { vation and investment policies of agpicultural organizations, aimed } \\
\text { at assessing the level of unemployment and real incomes of the } \\
\text { population; } \\
\text { 3) Transformation of the employment diversification process of ag } \\
\text { ticultural organizations }\end{array}$ & $\begin{array}{l}\text { 4. Analysis } \\
\text { of transfor- } \\
\text { mation of the } \\
\text { development } \\
\text { process }\end{array}$ & : \\
\hline$\frac{0}{0}$ & $\begin{array}{l}\text { 1) Transformation of the process of fast implementation of customs tariff } \\
\text { regulation measures in the imnovation and investment policy for the pur } \\
\text { pose of rationalizing the ratio of exports and imports of products, raw ma- } \\
\text { terials, and goods of agricultural complex; } \\
\text { 2) Transformation of the system of domestic producers dependence on the } \\
\text { mport of technologies, machinery, equipment and other resources of agrit } \\
\text { cultural organizations }\end{array}$ & $\begin{array}{l}\text { 5. Analysis } \\
\text { of the trans- } \\
\text { formation of } \\
\text { the foreign } \\
\text { economic } \\
\text { policy's } \\
\text { processes }\end{array}$ & : \\
\hline
\end{tabular}

Fig. 2. Groups of indicators of innovation and investment development of agricultural organizations for indicative methods (Source: compiled based on the study of theory and practice).

operations in technological production; 3) the presence of a mechanism that reduces the risks of the influence of weather conditions (nature and climate features); 4) the presence of a mechanism that reduces the level of applied physical force by working resources to the means of labor in the process of agricultural production;
5) the presence of a mechanism that provides a route for a year-round production; 6) the presence of a mechanism for the deep processing of products with aimed at resource conservation and modification; 7) the presence of cognitive digital technologies in the management of agricultural production in the agricultural sector; 8) the 
Table 1. Indicators of ontology and methodology of an innovative project in the agricultural industry.

\begin{tabular}{|l|l|l|l|}
\hline $\begin{array}{l}\text { No } \\
\boldsymbol{n n}\end{array}$ & Rank & Indicators & \multicolumn{1}{c|}{ Characteristics } \\
\hline 1 & $1(10 \%)$ & Inno_1 & $\begin{array}{l}\text { Completely new or "well" forgotten old ideas that were not implemented due to the lack of } \\
\text { mass knowledge, skills at a cognitive level }\end{array}$ \\
\hline 2 & $1(10 \%)$ & Inno_2 & Simplify the process, reducing the number of operations in technological production \\
\hline 3 & $2(9 \%)$ & Inno_3 & Reduces the risks of the influence of weather conditions (nature and climate features) \\
\hline 4 & $2(9 \%)$ & Inno_4 & $\begin{array}{l}\text { Reduces the level of applied physical force by working resources to the means of labor in the } \\
\text { process of agricultural production }\end{array}$ \\
\hline 5 & $2(9 \%)$ & Inno_5 & Provides a route for a year-round production \\
\hline 6 & $3(8 \%)$ & Inno_6 & Deep processing of products with aimed at resource conservation and modification \\
\hline 7 & $3(8 \%)$ & Inno_7 & $\begin{array}{l}\text { Cognitive digital technologies in the management of agricultural production in the agricultural } \\
\text { sector }\end{array}$ \\
\hline 8 & $3(8 \%)$ & Inno_8 & Increases production performance in the agricultural sector \\
\hline 9 & $3(8 \%)$ & Inno_9 & Enhances positive externalities \\
\hline 10 & $4(7 \%)$ & Inno_10 & Decreases negative externalities \\
\hline 11 & $4(7 \%)$ & Inno_11 & Builds the logic and evidence of indicators of causal analysis and synthesis \\
\hline 12 & $4(7 \%)$ & Inno_12 & Grades the risks of strategic drift \\
\hline \multicolumn{5}{|l}{ Total 100\% } \\
\hline Source: compiled based on the study of theory and practice. \\
\hline
\end{tabular}

presence of a mechanism that increases production performance in the agricultural sector; 9) the presence of a mechanism that enhances positive externalities; 10) the presence of a mechanism that decreases negative externalities; 11) the presence of a mechanism that builds the logic and evidence of indicators of causal analysis and synthesis; 12) the presence of a mechanism that grades the risks of strategic drift.

Indicators of ontology and methodology of an innovative project in the agricultural industry are presented in table 1 .

2. Indicators of ontology and methodology of investment design in agricultural activity can be formed as the following: 1) the presence of a logical project structure: hypothesis - relevance - goal and objectives innovativeness - production process - digital technology; the project should have a completely new or "well" forgotten old idea; 2) the presence of a mechanism that minimizes risks in the process of implementing an innovative project; 3) the presence of a mechanism to ensure food safety; 4) the presence of a mechanism that provides profit - the profitability of the project (sufficient and high); 5) the presence of a mechanism that ensures the possible implementation: resource security; territorial predisposition or strategic importance; 6) the presence of a mechanism that provides the ability to competently support business and labor resources; 7) the presence of a mechanism that provides high-quality contractual compilations between the subjects of an innovative project; 8) the existence of a mechanism that provides additional positive benefits or externalities; 9) available regional support and patronage of the project by the state; 10) the existence of a mechanism to ensure ethnic and territorial demands; 11) the possibility of obtaining a franchise for innovative techniques and production technologies; 12) the presence of a mechanism that provides tax preferences and benefits for the development of production in the area.

Table 2. Indicators of ontology and methodology of investment design in the agricultural industry.

\begin{tabular}{|c|c|c|c|}
\hline $\begin{array}{l}\text { No } \\
n n\end{array}$ & Rank & Indicators & Characteristics \\
\hline 1 & $\begin{array}{l}1 \\
(10 \%)\end{array}$ & Invst 1 & $\begin{array}{l}\text { Logical project structure: hypothesis - relevance - goal and objectives - innovativeness - } \\
\text { production process - digital technology; the project should have a completely new or "well" } \\
\text { forgotten old idea }\end{array}$ \\
\hline 2 & $1(10 \%)$ & Invst 2 & Minimization of risks in the process of implementing an innovative project \\
\hline 3 & $2(9 \%)$ & Invst 3 & Ensuring food safety \\
\hline 4 & $2(9 \%)$ & Invst 4 & Providing profit - the profitability of the project (sufficient and high) \\
\hline 5 & $2(9 \%)$ & Invst 5 & Possible implementation: resource security, territorial predisposition or strategic importance \\
\hline 6 & $3(8 \%)$ & Invst 6 & Ability to competently support business and labor resources \\
\hline 7 & $3(8 \%)$ & Invst 7 & Providing high-quality contractual compilations between the subjects of an innovative project \\
\hline 8 & $3(8 \%)$ & Invst 8 & Additional positive benefits or externalities \\
\hline 9 & $3(8 \%)$ & Invst 9 & Regional support and patronage of the project by the state \\
\hline 10 & $4(7 \%)$ & Invst 10 & Ensuring ethnic and territorial demands \\
\hline 11 & $4(7 \%)$ & Invst 11 & Possibility of obtaining a franchise for innovative techniques and production technologies \\
\hline 12 & $4(7 \%)$ & Invst 12 & Provides tax preferences and benefits for the development of production in the area \\
\hline & \multicolumn{3}{|c|}{ Total $100 \%$} \\
\hline
\end{tabular}


Table 3. Indicators of ontology and methodology of innovation and investment policy in agriculture.

\begin{tabular}{|c|c|c|c|}
\hline $\begin{array}{l}\text { № } \\
\text { nn }\end{array}$ & $\begin{array}{l}\text { Rank } \\
(\%)\end{array}$ & Indicators & Characteristics \\
\hline 1 & $\begin{array}{l}1 \\
(10 \%)\end{array}$ & Inno-Invst_1 & $\begin{array}{l}\text { Logical structure of the innovation and investment project which reflects a completely new } \\
\text { or "well" forgotten old idea; the consistency of such attributes of investment work as: } \\
\text { hypothesis - relevance - goal and objectives - innovation - production process - digital } \\
\text { technology - project lifetimes - life cycle stages - liquidation techniques or project } \\
\text { modernization - control of liquidation results or project modernization }\end{array}$ \\
\hline 2 & $1(10 \%)$ & Inno-Invst_2 & $\begin{array}{l}\text { Simplify the process (reducing the number of operations in agricultural production); focus } \\
\text { on minimizing risks in the process of implementing an innovative project }\end{array}$ \\
\hline 3 & $2(9 \%)$ & Inno-Invst_3 & $\begin{array}{l}\text { Reduces the risks of the impact of weather conditions (nature and climate features), } \\
\text { ensuring national food security }\end{array}$ \\
\hline 4 & $2(9 \%)$ & Inno-Invst_4 & $\begin{array}{l}\text { Decreases the level of applied physical force by labor resources to the means of labor in } \\
\text { the process of agricultural production, while increasing profitability from a sufficient level } \\
\text { to high }\end{array}$ \\
\hline 5 & $2(9 \%)$ & Inno-Invst_5 & $\begin{array}{l}\text { Provides routes to year-round production with confirmed certainty and availability of the } \\
\text { necessary resources, as well as the area disposition or strategic importance of the } \\
\text { innovation project }\end{array}$ \\
\hline 6 & $3(8 \%)$ & Inno-Invst_6 & $\begin{array}{l}\text { Provides deep (non-waste) processing of products aimed at resource saving and } \\
\text { modification based on the availability of competent support with labor resources }\end{array}$ \\
\hline 7 & $3(8 \%)$ & Inno-Invst_7 & $\begin{array}{l}\text { Providing cognitive digital technologies in the management of agricultural production on } \\
\text { the basis of high-quality contractual compilations between the subjects of the innovation } \\
\text { project }\end{array}$ \\
\hline 8 & $3(8 \%)$ & Inno-Invst_8 & $\begin{array}{l}\text { Increases agricultural performance in the agro-industrial complex upon receiving } \\
\text { additional effects (externalities) }\end{array}$ \\
\hline 9 & $3(8 \%)$ & Inno-Invst_9 & $\begin{array}{l}\text { Enhances positive externalities that determine benefits for third parties, providing regional } \\
\text { support and patronage of the project from the state in the process of implementing an } \\
\text { innovative project }\end{array}$ \\
\hline 10 & $4(7 \%)$ & Inno-Invst_10 & $\begin{array}{l}\text { Reduces negative externalities that determine damage to third parties ensuring ethnic and } \\
\text { area requests }\end{array}$ \\
\hline 11 & $4(7 \%)$ & Inno-Invst_11 & $\begin{array}{l}\text { Ensures the consistency and evidence of causal analysis and synthesis of ethnic and area } \\
\text { issues with the possibility of a franchise on agricultural technology for the production of } \\
\text { the ongoing project }\end{array}$ \\
\hline 12 & $4(7 \%)$ & Inno-Invst_12 & $\begin{array}{l}\text { Provides mitigation the risks of strategic drift with the possibility of registration or } \\
\text { adoption of tax preferences }\end{array}$ \\
\hline & \multicolumn{3}{|c|}{ Total Rank $4(100 \%)$} \\
\hline
\end{tabular}

Indicators of ontology and methodology of investment design in the agricultural sector are presented in table 2.

3. Indicators of ontology and methodology of innovation and investment policy in agricultural activities. It is essential to study synthetic indicators that combine all aspects and problems of investing of an innovative project, which is supposed to be implemented. At this stage, the following components are subject to diagnosis: 1) the presence of a logical structure of the innovation and investment project, which reflects a completely new or "well" forgotten old idea; the consistency of such attributes of investment work as: hypothesis - relevance - goal and objectives - innovation - production process - digital technology - project lifetimes - life cycle stages - liquidation techniques or project modernization - control of liquidation results or project modernization; 2) the presence of mechanisms to simplify the process (reducing the number of operations in agricultural production); focus on minimizing risks in the process of implementing an innovative project; 3 ) the presence of a mechanism that reduces the risks of the impact of weather conditions (nature and climate features), ensuring national food security; 4) the presence of a mechanism that decreases the level of applied physical force by labor resources to the means of labor in the process of agricultural production, while increasing profitability from a sufficient level to high; 5) the existence of a mechanism that provides routes to year-round production with confirmed certainty and availability of the necessary resources, as well as the area disposition or strategic importance of the innovation project; 6) the presence of a mechanism that provides deep (non-waste) processing of products aimed at resource saving and modification based on the availability of competent support with labor resources; 7) the presence of cognitive digital technologies in the management of agricultural production on the basis of high-quality contractual compilations between the subjects of the innovation project; 8) the presence of a mechanism that increases agricultural performance in the agro-industrial complex upon receiving additional effects (externalities); 9) the presence of a mechanism that enhances positive externalities that determine benefits for third parties, providing regional support and patronage of the project from the state in the process of implementing an innovative project; 10) the existence of a mechanism that reduces negative externalities that determine damage to third parties ensuring ethnic and area requests; 11) the existence of a mechanism to 
ensure the consistency and evidence of causal analysis and synthesis of ethnic and area issues with the possibility of a franchise on agricultural technology for the production of the ongoing project; 12) the existence of a mechanism to mitigate the risks of strategic drift with the possibility of registration or adoption of tax preferences. Indicators of ontology and methodology of innovation and investment policy in the agricultural sector are presented in table 3 .

Diagnosis is drawn up in the expert's working paper "Diagnosis of innovation and investment policy in the agricultural sector", which has three possible answers to the question posed: "yes", "partly", "no".

\section{Conclusion}

The innovation and investment policy of agricultural organizations is a focused activity aimed at solving the problems of the agro-industrial complex, to achieve and implement generally significant goals, expressing dominant priorities and values of adopting innovative investment tools. The development of a system of indicators in the management of innovation and investment readiness in the context of digital and technological transformation from the perspective of an ontological approach will make it possible to control the process of achieving specific goals of production and sales of agricultural products, using new technologies, relying not only on our own resources, but also on attracted investments.

\section{Acknowledgements}

The reported study was funded by the Russian Foundation for Basic Research grant No. 19-010-00985 A. "Development of innovative and investment policy as a concept of strategic economic security of agricultural organizations in the conditions of the modern technological transformation".

\section{References}

1. K.G. Asriyants, M.M. Aliev, Development of a competitive strategy for agricultural processing industry enterprises, Regional problems of economic transformation 11, 60-70 (2016).

2. Y.V. Melnikova, A.V. Shokhnekh, Forming the policy of insurance of innovative and investment activities of agricultural organizations as a conceptstrategy of provision of economic and food security, Lecture Notes in Networks and Systems 87, 809-816 (2020).

3. A.F. Rogachev, A.V. Shokhnekh, Genesis of mathematical models of econophysics as a path to food security, Audit and financial analysis 1, 410413 (2015).

4. N.N. Rumbaeva, Transformation of land ownership in the agro-industrial sector of the regions of Russia, Regionology 1, 58, 132-137 (2007).
5. A.M. Shogenov, Organizational and economic mechanism of transformation and development of regional agriculture, Economic analysis: theory and practice 11, 26, 57-61 (2004).

6. M.N. Kunitsa, Features of the modern transformation of the agricultural complex of the Bryansk region, Bulletin of agrarian science 6, 69, 124-131 (2017).

7. I.A. Ganieva, Digital transformation of Russian agriculture: consolidation of the state and agricultural business, Achievements of science and technology of the agro-industrial complex 33, 4, 57 (2019).

8. Y.A. Gerasina, L.V. Barmashova, O.N. Denisova, The economic essence of the innovation and investment process in modern corporations, Problems of Economics and Legal Practice, 217220 (2011).

9. N.N. Makarova, A.V. Shokhnekh, Synergetic Approach to The Formation of The Innovative Investment Policy of Enterprises in The AgroIndustrial Complex: Goal-Setting and Forecasting, International Journal of Recent Technology and Engineering (IJRTE) 8, 1, 2688-2690 (2019).

10. T.M. Gerashchenkova, About factors of ensuring the effectiveness of innovation-investment processes, Bulletin of Novgorod State University of Yaroslav the Wise, 76, 77-82 (2014).

11. A.L. Gladysheva, O.N. Gorbunova, I.F. Chepurova, Human resources and innovations as the most important components of a company's competitive advantages, Social and economic phenomenon and processes 9, 11, 34-38 (2014).

12. V.A. Salomatin, Innovative processes in the agricultural sector: the nature and directions of development, Theory and practice of social development, 8, 295-299 (2011).

13. Y.V. Melnikova, A.V. Shokhnekh, Forming the policy of insurance of innovative and investment activities of agricultural organizations as a conceptstrategy of provision of economic and food security, Lecture Notes in Networks and Systems 87, 809-816 (2020).

14. T.A. Shcherbina, Digital transformation of agriculture of the Russian Federation: experience and prospects, Russia: trends and development prospects, 450-453 (2019).

15. A.V. Shokhnekh, Y.V. Melnikova, T.M. Gamayunova, The investment concept strategy of development of innovative activities of agricultural organizations in the conditions of techno-economic modernization, Lecture Notes in Networks and Systems 87, 796-808 (2020).

16. A.V. Shokhnekh, O.A. Mironova, L.R. .Moiseeva, L.Y. Yakovleva, A.K. Evstafieva, Provision of innovational and economic security of small business in the internet space of cyber-economy on the platform of cognitive assistants of artificial intelligence, Studies in Computational Intelligence 826, 1023-1029 (2019).

17. A.R. Saifetdinov, M.E. Trubilin, G.G. Grateful, P.V. Puzeychuk, Features of innovation and 
investment transformation of enterprises and sectors of the agro-industrial complex, Colloquiumjournal 11-9, 22, 83-87 (2018).

18. T.I. Grudkina, T.S. Khomaiko, A.O. Lelyakin, Increasing the efficiency of crop production and creating of competitive advantages by agricultural business entities, Concept, 6, 1-9 (2014).

19. V.M. Taroyan, Innovations in Human Resource Management, Bulletin of the St. Petersburg State University of Economics 2, 92, 120-122 (2015).

20. G.A. Dryomina, The use of technological innovation in the reengineering of banking, Omsk Scientific Herald, 104-107 (2012).

21. A.F. Rogachev, E.V. Melikhova, A.V. Shokhnekh, Monitoring and economic \& mathematical modeling of manufacture and consumption of agricultural products as a tool of food security management, Espacios 39, 1, 1 (2018).

21. Yu.V. Melnikova, A.V. Shokhnekh, ed. A.V. Shokhnekh, Genesis and ontology of innovation and investment policy as a concept of economic security of agricultural organizations in the conditions of digital transformation: monograph (Ufa, 170, 2019). 